\title{
Thermal treatment for soybean flour processing with high-quality color and reduced Kunitz trypsin inhibitor
}

\author{
Alice Maria Dahmer ${ }^{1}$ | Aline Andressa Rigo $^{1} \mid$ Juliana Steffens $^{1} \odot$ | Clarice Steffens ${ }^{1} \odot$ | \\ Mercedes Concordia Carrão-Panizzi ${ }^{2}$
}

${ }^{1}$ Department of Food Engineering, URI Erechim Campus, Erechim, Brazil

${ }^{2}$ Embrapa Trigo - Rodovia BR-285, Passo Fundo, Brazil

Correspondence

Juliana Steffens, Av. Sete de Setembro 1621, Erechim-RS, 99700-000, Brazil.

Email: julisteffens@uricer.edu.br

Funding information

CNPQ, Grant/Award Number:

471593/2012-5

\begin{abstract}
In this work thermal treatment was applied in whole soybean flour and bleached whole soybean flour production aimed at Kunitz trypsin inhibitor (KTI) reduction and color. A $2^{2}$ Central Composite Rotational Design was developed to evaluate the effects of temperature $\left(91.80-148.20^{\circ} \mathrm{C}\right)$ and time (15.9-44.10 $\left.\mathrm{min}\right)$. In general, the bleached whole soybean flour presented higher $\mathrm{KTI}$ reduction and better color than whole soybean flour in the evaluated temperature and time ranges. It was observed that at $148.2{ }^{\circ} \mathrm{C}$ for $30 \mathrm{~min}$ the whole soybean flour presented a lower KTI value $(1.56 \mathrm{mg} / \mathrm{g})$ than bleached whole soybean flour $(1.48 \mathrm{mg} / \mathrm{g})$ and good luminosity. As the bleached presents an extra step in the treatment process, new experiments were made with whole soybean flour without bleached to evaluate $\mathrm{KTI}$ and color reduction as a time function (10-30 $\mathrm{min}$ ) at $148.2{ }^{\circ} \mathrm{C}$. The time was evaluated the verify the behavior of $\mathrm{KTI}$ and color of whole soybean flour. The treatment at $148.2^{\circ} \mathrm{C}$ for 20 and 30 min presented the lowest KTI values, however, the $L *$ color value at $20 \mathrm{~min}$ was higher and soybean flour was whiter, hence 20 min was considered the best condition for whole soybean flour production.
\end{abstract}

\section{Practical applications}

In order to increase the nutritional quality of soybeans and use them as food, the inactivation of protease inhibitors is required. As soybean nutritional value is adversely affected by protease inhibitors presence that are considered anti-nutritional factors, these need to be eliminated. Thermal treatment has been used as a physical method to inactivate these factors. However, it must be controlled to avoid essential amino acids destruction. Thermal treatment prior to soybean processing for flour production is common. However, recommendation for the best time and temperature for the grains is nonexistent in order to inactivate and/or reduce their phytochemicals with anti-nutritional action, to the detriment of those with functional effect, preserving their nutrients. Usually, commercial soybean products are thermally treated with less than $20 \%$ of in natura soybean trypsin inhibitory activity.

\section{1 | INTRODUCTION}

Soybean is a highly nutritional vegetable and an important protein source (38-44\%), with a good essential amino acids. However, it is estimated that $6 \%$ of these proteins are protease inhibitors (PI) (Fang, Leung, Fang, \& Ng, 2012). Studies have indicated that PI present a variety of physiological functions in plants, it can act as endogenous proteases regulators, reserve proteins, plant defense agents against insects, fungi, bacteria, and other herbivorous animals (Vagadia, Vanga, \& Raghavan, 2017). Besides that, they act during seed germination, vegetative development, and cell death (Vorster et al., 2013).

However, in monogastric animals, experimental evidence shows that active PIs deleterious effects on diet cause mainly a growth rate reduction and metabolic alterations of the pancreas, such as increased 
enzymatic secretion, hypertrophy, and hyperplasia (Brune, Pinto, Peluzio, Moreira, \& Barros, 2010; Gemede \& Ratta, 2014). This is due to intestinal proteolysis inhibition, meaning relevant endogenous sulfur amino acid losses, affecting the biological value and bioavailability of nutrients (Coscueta et al., 2017). However, positive physiological effects such as carcinogenesis suppression and anti-inflammatory activity in several in vitro and animal studies were associated with soy products found in the diet, BowmanBirk-Inhibitor (BBI) PI type being the main one involved (Dan \& Ng, 2016; Gemede \& Ratta, 2014).

The digestibility and quality of mixed diets in developing countries is considerably lower compared to proteins found typical North American diets (54-78 against 88-94\%) (Gilani, Xiao, \& Cockell, 2012), respectively. The lower proteins digestibility is based on the ingestion of less refined grains and vegetables as the main protein sources, the presence of less digestible protein fractions, high insoluble fiber levels, endogenous anti-nutritional factors, and factors formed during processing.

The Kunitz trypsin inhibitor (KTI), a soybean $\mathrm{PI}$, is sensitive to thermal treatment and has specificity for trypsin, whereas the BBI one is more thermo-stable, capable to inhibit trypsin and chymotrypsin (Chen, Xu, Zhang, Kong, \& Hua, 2014; Galão et al., 2014).

Thermal inactivation or minimization of Pls is required in order to increase the nutritional value of soybean. Pls can be easily denatured by thermal treatment due to their protein nature, so temperature and exposure time are critical in the production process. However, the heating intensity applied during such treatment should be controlled, since under-heating or over-heating may reduce the number of nutrients, resulting in a poor-quality of the product. Flavor, color, and vitamin contents are also affected depending on the type of thermal treatment used.

Soy products for human consumption must undergo sufficient thermal treatment in order to inactivate a minimum of $80 \%$ trypsin activity (Cardoso et al., 2007). Thermal treatment is the most commonly applied method for soybean flour processing, including extrusion, forced-air oven treatment, autoclaving, and roasting. Among the mentioned methods, the oven treatment is a more basic, easyhandling and simpler process. Grains bleaching can reduce the lipidsoluble vitamin and essential fatty acid contents, and carotenoids loss, implying in soybean flour color variations, which could be used with one step before the oven treatment.

In this sense, studies in order to obtain soybean flour are important, and the production using thermal treatment must be carefully conducted to maintain the natural coloration and/or reduce the undesirable coloration.

The aim of this study was to evaluate the effects of temperature $\left(91.80-148.20^{\circ} \mathrm{C}\right.$ ) and time $(15.9-44.10 \mathrm{~min})$ by thermal treatment (roasting) applying a $2^{2}$ central composite rotatable design (CCRD) in whole soybean flour and bleached whole soybean flour using BRS 267 soybean, genetically improved cultivar, in relation to KTI residual levels and color. In addition, was evaluated the soybean flour with lower KTI and good color in terms of physicalchemical composition, nitrogen solubility index, protein dispersibility index, and fatty acids.

\section{2 | MATERIAL AND METHODS}

\section{1 | Materials}

The BRS 267 soybean (Glycine max) developed by the Brazilian Agricultural Research Company (Embrapa), 2012/2013 harvest, produced in Passo Fundo, RS-Brazil was used in this study. This human-consumption-cultivar presents distinctive characteristics, such as above average size grains, yellow hilum, a mild and sweet flavor, high sucrose and amino acids (glutamic acid and alanine) contents, and is classified as a vegetable soybean cultivar.

\section{2 | Soybean flour}

The $2^{2}$ central composite rotatable design (CCRD) with 11 experiments was used in order to study the effects of color ( $L^{*}, a^{*}$, and $\left.b^{*}\right)$ and $\mathrm{KTI}$ in soybean flours, where the independent variables (temperature $91.80-148.20{ }^{\circ} \mathrm{C}$ and time $15.9-44.10 \mathrm{~min}$ ) were evaluated. The CCRD is an optimal design allowing calculation of the effects and interactions for each chosen factor.

Whole soybean and bleached whole soybean flours were obtained. Initially, the samples were manually cleaned for impurities, broken and imperfect grains removal. About $50 \mathrm{~g}( \pm 1.0)$ grains were distributed in Petri dishes (14 cm diameter) and submitted to thermal treatment (oven treatment) in an air-circulating oven (Fanem, 320-SE model). Afterward, the samples were cooled to room temperature in a desiccator. Then, the grains were milled in a mill (Cuisinart mill, DCG20BKN model) and submitted to manual sieving in a 42 mesh siever (Bertel). The flour was packed in plastic containers and stored under refrigeration $\left(8-10^{\circ} \mathrm{C}\right)$ for subsequent color and $\mathrm{KTI}$ determinations.

For bleached whole soybean flour production, a hydrothermal/ bleaching treatment $\left(98^{\circ} \mathrm{C}\right.$, for $5 \mathrm{~min}$ ) was applied after cleaning. After immersion in water (bleaching), the grains were cooled in an ice bath for $4 \mathrm{~min}$, drained and placed in Petri dishes forming a single layer. Afterward, the samples were placed in an air circulation drying oven at $40{ }^{\circ} \mathrm{C}$ for $24 \mathrm{hr}$ until reaching a constant weight. Then, the thermal treatment for bleached whole soybean flour was performed under the same experimental design conditions used for whole soybean flour.

Whole soybean flour and bleached whole soybean flour samples were submitted to the instrumental color and KTI analyses. In order to study the optimized condition, to reduce $\mathrm{KTI}$ and to obtain the high color value $\left(L^{*}, a^{*}\right.$, and $\left.b^{*}\right)$, thermal treatment was carried out at $148.2^{\circ} \mathrm{C}$, at different times $(10,15,20$, and $30 \mathrm{~min})$. For the soybean flour obtained with best processing conditions using thermal treatment $\left(148.2{ }^{\circ} \mathrm{C}\right.$ for $\left.20 \mathrm{~min}\right)$ were performed the analysis of moisture, ash, protein, total fiber, lipid, nitrogen solubility index (NSI), protein dispersibility index, and fatty acid profile.

\section{3 | Physical-chemical analyses}

Instrumental color was determined using a colorimeter (Minolta CR400) with a D65 light source, expressing the results in CIELAB color space $\left(L^{*}, a^{*}\right.$, and $\left.b^{*}\right)$. 
KTI was determined both in grains and soybean flours according to method by Hamerstrand (1981). The applied method is based on the trypsin inhibition degree and benzoyl-DL-arginine p-nitroanilide hydrochloride substrate (BAPA) hydrolysis. The results were expressed in $\mathrm{mg} / 100 \mathrm{~g}$ on a dry weight basis.

Moisture, ash, protein, total fiber, and lipid analyses were performed in according to AOAC (2007) method. The results were expressed in $\mathrm{g} / 100 \mathrm{~g}$ on a dry weight basis.

Nitrogen solubility index (NSI) and protein dispersibility index (PDI) were measured according to AOCS (1980). The crude protein was determined by AOAC (2007).

The fatty acid profile was determined by gas chromatography (Christie, 1989). A $0.200 \mathrm{~g}$ sample was transferred to $50 \mathrm{~mL}$ screwcap Falcon tubes. The methylation for subsequent injection was performed by adding $5 \mathrm{~mL}$ of $1 \%$ sodium methoxide in methanol, followed by stirring at 15 -min intervals, for $60 \mathrm{~min}$. Afterward, $1 \mathrm{~mL}$ of $10 \%$ acetic acid and $10 \mathrm{~mL}$-heptane were added for acidification and stirred for $10 \mathrm{~s}$. The samples were left sitting for $10 \mathrm{~min}$ for phase separation and $2 \mathrm{~mL}$ of the upper phase, containing the fatty acid methyl esters, previously solubilized in heptane, were pipetted into glass vials. About $2 \mu \mathrm{L}$ methylated sample was injected into a Trace Ultra Gas GC chromatograph equipped with a Supelco SP-2340 capillary silica column. The injection was performed in split mode (20:1) at $250{ }^{\circ} \mathrm{C}$, and separation was carried out at a $170{ }^{\circ} \mathrm{C}$ initial temperature and heating ramp up to $220^{\circ} \mathrm{C}$ in $15 \mathrm{~min}$. Detection was performed by flame ionization at $300{ }^{\circ} \mathrm{C}$. Gas flow was set at $40 \mathrm{~mL} / \mathrm{min}$ for nitrogen and hydrogen, and $450 \mathrm{~mL} / \mathrm{min}$ for synthetic air. The total running time for each sample was $18 \mathrm{~min}$. Fatty acid quantification was performed by external standard (calibration curves) with the usual concentrations of respective fatty acids methyl ester (Fame, SigmaAldrich) standards.

\section{4 | Statistical analysis}

The experimental design completely randomized for each treatment, and the chemical analysis were both performed in triplicate. The results were subjected to Student and Tukey test at a 95\% confidence level using Statistica 5.0 software (StatSoft, The United States).

\section{RESULTS AND DISCUSSION}

\section{1 | Thermal treatment effect on color and KTI}

Experimental design was carried out using in natura and bleached soybean grains submitted to thermal treatment at different temperatures and time periods in order to obtain whole soybean flour and bleached whole soybean flour, and the results of color and $\mathrm{KTI}$ are presented in Table 1.

In general, the luminosity $\left(L^{*}\right)$ values decreased with the increase of temperature and time on treatments, hence darkening the flours. It is observed that $L *$ variation range was lower for whole soybean flour (79.79-89.80) than for bleached whole soybean flour (68.01-88.16) and the whole soybean flour $L^{*}$ value was greater than the bleached whole soybean flour one for the same treatment with significant difference $(p<.05)$. The thermal treatment (at high temperatures) in the bleached whole soybean flour, possibly influenced dimming reactions, by lowering luminosity.

The $a^{*}$ values increased in the flours in relation to the in natura grains, demonstrating significant original color loss $(p<.05)$, which was more intense at high temperatures and long time periods, and represented by the positive values. Comparing both flours, it can be observed that bleaching treatment increased $a^{*}$ values mainly for treatments 4 and 6, with high temperatures ( 140 and $148.2{ }^{\circ} \mathrm{C}$ ) for at least $30 \mathrm{~min}$. The $a^{*}$ values for assays 1, 3, 5, and 7 for whole soybean flour and assays 1,3 , and 5 for bleached whole soybean flour indicated the green color component, due to lower temperatures applied in the treatment.

For $b^{*}$, whole soybean flour values were always lower than the bleached whole soybean flour ones for the same treatment, indicating that bleaching can provide a more yellowish hue on flour. Higher $b^{*}$ values were observed in assays 4 and 6 for both flours.

Thus, thermal treatment conditions (temperature and time) has significant influence $(p<.05)$ in the color parameters $\left(L^{*}, a^{*}\right.$, and $\left.b^{*}\right)$ for whole soybean flour, with luminosity, yellow intensity, and red color values variations.

The analysis of variance validated the model for $L^{*}, a^{*}$, and $b^{*}$ color coordinates for whole soybean flour, obtaining $0.98,0.99$, and 0.97 correlation coefficients, and the $F$ calculated were 6.99, 23.53, and 3.28 times higher than the values listed in statistical tables, respectively, allowing the contour curve construction, as seen in Figure 1. Equations (1)-(3) presents the second-order coded model, which describes the $L^{*}, a^{*}$, and $b^{*}$ color coordinates for whole soybean flour as a function of independent variables (factors) analyzed (temperature and time), within the studied range.

$$
\begin{gathered}
L^{*}=88.19-2.646 x_{1}-1.90 x_{1}^{2}-0.90 x_{1} x_{2} \\
a^{*}=0.34+1.68 x_{1}+0.78 x_{1}^{2}+0.32 x_{2}-0.20 x_{2}^{2}+0.41 x_{1} x_{2} \\
b^{*}=17.79+1.25 x_{1}+1.35 x_{1}^{2}+0.34 x_{2}+0.81 x_{1} x_{2}
\end{gathered}
$$

where, $x_{1}$ is temperature $\left({ }^{\circ} \mathrm{C}\right)$ and $x_{2}$ is time (min).

The contour curve response (Figure 1 a) show that the smaller $L^{*}$ values were obtained from the highest temperatures and longest time, resulting in a darker soybean flour color. Higher temperature and longer time influenced negatively the color, causing greater pigments formation, probably due to the Maillard reaction. The temperature had the greatest influence in the process since at 140 and $148.2{ }^{\circ} \mathrm{C}$, lower $L^{*}$ values were obtained. Greater $L^{*}$ values were observed at intermediate temperatures, between 100 and $120^{\circ} \mathrm{C}$, at any set time. Redder tones were obtained at longer times and higher temperatures (Figure $1 \mathrm{~b}$ ). Chromaticity $a^{*}$ presented lower temperatures and shorter times values in the green region.

In Figure 1c, it was found that higher temperatures and longer periods of time tend to increase $b^{*}$ chromaticity, with yellow color intensification. It was observed that in intermediate temperatures of the treatment, color $b^{*}$ value was lower, resulting in a less-yellowcolor intensity flour.

Shin, Kim, and Kim (2013) observed that the soybean flour obtained from (Taekwangkong; Glycine max [L.] Merrill), roasted at 


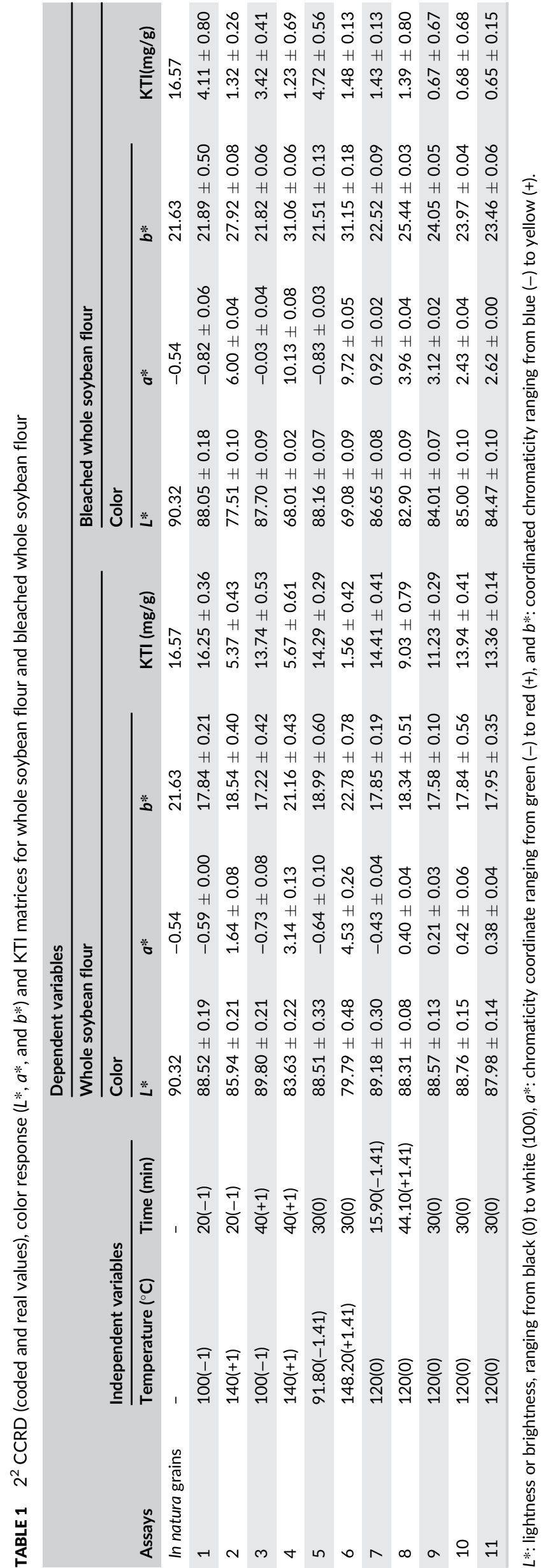

$140{ }^{\circ} \mathrm{C}$ for $30 \mathrm{~min}$, presented $89.96,-0.82$, and 20.76 for $L^{*}, a^{*}$, and $b^{*}$ values, respectively. These values are comparable to the ones obtained in this study under lower temperature and shorter time periods.

Factors such as genetics of cultivars, environmental conditions, location, crop yield, planting season, region, harvesting, and storage conditions may also affect the soybean structural parts' composition and proportionality. Moisture can also influence on color as reported by Shin et al. (2013), who compared raw soy flour (10.35\% moisture and $\left.L^{*}=92.4\right)$ with steamed soy $\left(11.11 \%\right.$ and $\left.L^{*}=90.5\right)$ and roasted soy $\left(3.53 \%\right.$ and $\left.L^{*}=89.9\right)$ flours. In the present work since grains had the same moisture $(\sim 7.8 \%)$ values before the flours preparation, it is assumed that color of flours were not affected by moisture.

Overall, soybean flour color parameter variation occured due to different thermal processes, mainly due temperature and time applied. Thermal treatment with lower temperature and shorter time can provide a lighter-colored flour.

The models for bleached whole soybean flour in relation to color parameters were validated by the analysis of variance. The correlation coefficient of 0.99 was similar for all analyzed coordinates ( $L^{*}, a^{*}$, and $\left.b^{*}\right)$. The $\mathrm{F}$ calculated values were $12.97,26.67$, and 20.87 times greater than the $\mathrm{F}$ tabulated ones for $L^{*}, a^{*}$, and $b^{*}$, respectively. Equations (4)-(6) present the second-order coded model, which describes $L^{*}, a^{*}$, and $b^{*}$, as a function of the independent variables (factors) analyzed (temperature and time), within the studied range.

$$
\begin{aligned}
& L^{*}=84.50-7.16 x_{1}-3.30 x_{1}^{2}-1.90 x_{2}-2.29 x_{1} x_{2} \\
& a^{*}=2.72+3.99 x_{1}+0.96 x_{1}^{2}+1.15 x_{2}+0.84 x_{1} x_{2} \\
& b^{*}=23.82+3.62 x_{1}+1.39 x_{1}^{2}+0.90 x_{2}+0.80 x_{1} x_{2}
\end{aligned}
$$

where, $x_{1}$ is temperature $\left({ }^{\circ} \mathrm{C}\right)$ and $x_{2}$ is time $(\mathrm{min})$.

The lowest $L^{*}$ responses were obtained at the highest temperature and longest time period (Figure 2a). In this way, long time periods and high temperatures negatively influence the white color of flour. The $a^{*}$ chromaticity (Figure 2b) presented increasing values, tending to a red coloring. The $b^{*}$ chromaticity tended to increase at high temperatures and long time periods with a yellow coloring intensification (Figure 2c).

When comparing whole soybean flour and bleached whole soybean flour color parameters, it was noted that the bleaching treatment darkened it (lower $L *$ ), with high red ( $a *$ increase), and yellow intensities ( $b *$ increase). Possibly, bleaching changed the molecular conformation of proteins (denaturation) (Ciabotti, Barcelos, Pinheiro, Clemente, \& Lima, 2007) and promoted the molecular structures disruption, favoring nonenzymatic darkening reactions.

Soybean flour production could be carried out in a manner that would keep a close-to-natural coloration or at the very least reduce the occurrence of any undesirable coloration. Very low luminosity, for instance, could induce a fairly dark color to the final product that would restrict its use in by-products. It is also quite important to note that darkening occurs at the expense of nutrients, reducing nutritional and sensory qualities of the flours. Therefore, thermal treatment ought to be adequate to diminish the antinutritional factors while maintaining the nutritional properties of food. 

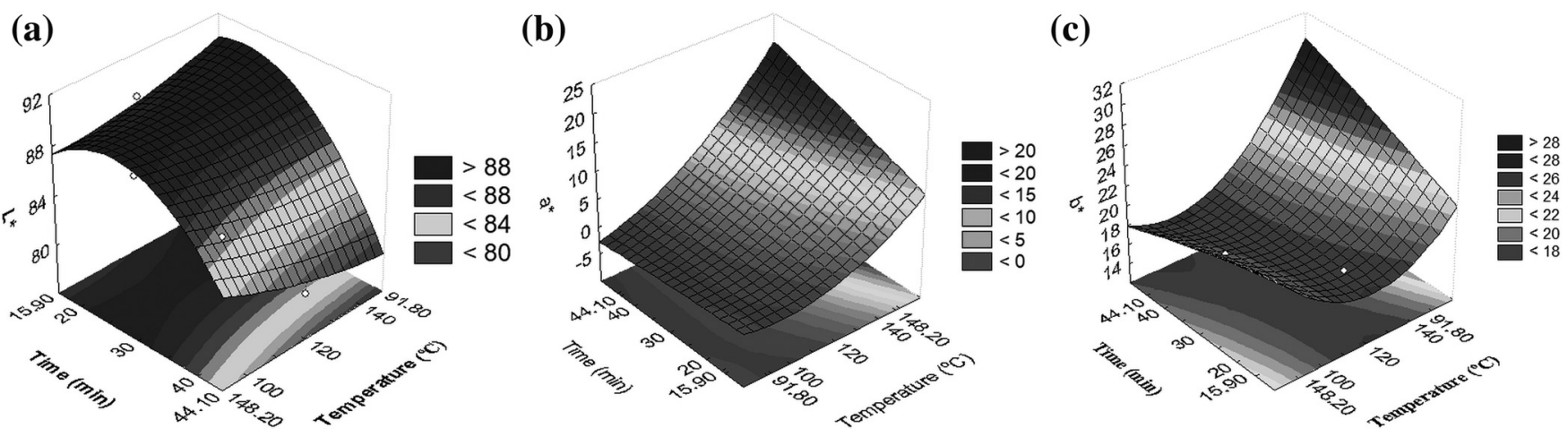

FIGURE 1 Response surface for variables $L^{*}(\mathrm{a}), a^{*}(\mathrm{~b})$, and $b^{*}(\mathrm{c})$ as a function of time and temperature in whole soybean flour

KTI responses for bleached whole soybean flour were significantly low in relation to the whole soybean flour, except for assay 5. This reduction was a result of prior bleaching applied to the grains. The bleaching and thermal treatment combination promoted KTI reduction. Soybean products for human consumption must undergo sufficient thermal treatment to inactivate $80 \% \mathrm{KTI}$ activity at the very least (Cardoso et al., 2007). Therefore, all treatments of this study that presented $\mathrm{KTI}$ values lower than $3.3 \mathrm{mg} / \mathrm{g}$ were suitable.

Equations (7) and (8) showed the second order-coded model for KTI parameters in the whole soybean and bleached whole soybean flours, validated by the analysis of variance, respectively. The nonsignificant parameters were added to the lack of fit for the analysis of variance (ANOVA). The correlation coefficients were 0.99 and 0.98 , for whole soybean flour and bleached whole soybean flour, respectively. The $\mathrm{F}$ calculated values were 8.71 and 5.19 times greater than the $\mathrm{F}$ tabulated ones, allowing the response surface construction (Figure 3 ).

$$
\begin{gathered}
\mathrm{KTI}_{1}=12.84-4.63 x_{1}-2.36 x_{1}^{2}-1.23 x_{2} \\
\mathrm{KTI}_{2}=0.67-1.02 x_{1}+1.48 x_{1}^{2}-0.10 x_{2}+0.37 x_{2}^{2}+0.15 x_{1} x_{2}
\end{gathered}
$$

where, $\mathrm{KTI}_{1}$ is the whole soybean flour, $\mathrm{KTI}_{2}$ is the bleached soybean flour, $x_{1}$ is temperature, and $x_{2}$ is time.

Smaller KTI responses for whole soybean flour were obtained at high temperatures (Figure 3a). The optimal treatments for bleached whole soybean flour production (Figure 3b) were achieved at $120^{\circ} \mathrm{C}$ for $30 \mathrm{~min}$, corresponding to the central point (assays 9-11). The significant $\mathrm{KTI}$ reduction on the flours with thermal treatment might have been due to its heat-labile nature.
The higher $\mathrm{KTI}$ values obtained in both soybean treatments (Table 1), were lower than the ones found in the literature. Andrade, Mandarino, Kurozawa, and Ida (2016), when obtaining whole soybean flour in an oven at $200^{\circ} \mathrm{C}$ for $20 \mathrm{~min}$, observed a minimum $32.67 \mathrm{mg} / \mathrm{g}$ KTI. Kaur, Sharma, Dar, and Singh (2012), in cereal brans subjected to dry heat (in an air-circulating oven), obtained $11.54 \mathrm{mg} / \mathrm{g}$ $\mathrm{KTI}$ at $115^{\circ} \mathrm{C}$ for $25 \mathrm{~min}$. Thus, the thermal processing studied in the present study was effective in anti-nutritional factors reduction.

In assay 6 treated at $148.2^{\circ} \mathrm{C}$ for $30 \mathrm{~min}$, it was observed that the whole soybean flour presented a similar $\mathrm{KTI}$ value $(1.56 \mathrm{mg} / \mathrm{g})$ to the bleached whole soybean flour $(1.48 \mathrm{mg} / \mathrm{g}$ ) and good luminosity in the flour. In this way, this treatment was chosen for new experiments in order to evaluate $\mathrm{KTI}$ and color reduction as a time function $(10,15$, 20 , and $30 \mathrm{~min}$ ) at $148.2^{\circ} \mathrm{C}$. In addition, the whole soybean flour production would appeal for domestic and small-scale production as it has an easier flow without the bleaching stages, since the bleaching process requires a sequential water-dependent thermal treatment.

\section{2 | Thermal treatment at $148.2{ }^{\circ} \mathrm{C}$ in whole soybean flour at different times}

Table 2 show the results on KTI and color $\left(L^{*}, a^{*}\right.$, and $\left.b^{*}\right)$ for whole soybean flour subject to thermal treatment $\left(148.2^{\circ} \mathrm{C}\right)$ in different times $(10,15,20$, and $30 \mathrm{~min}) . \mathrm{KTI}$ reduction was time-dependent, despite no significant differences ( $p>.05$ ) observed between 20 and $30 \mathrm{~min}$, and also between 10 and $15 \mathrm{~min}$. An inhibitor reduction up to $80 \%$ is important for human consumption (Cardoso et al., 2007). In natura grains showed $16.57 \mathrm{mg} / \mathrm{g}$ inhibitor, however, when submitted to (a)

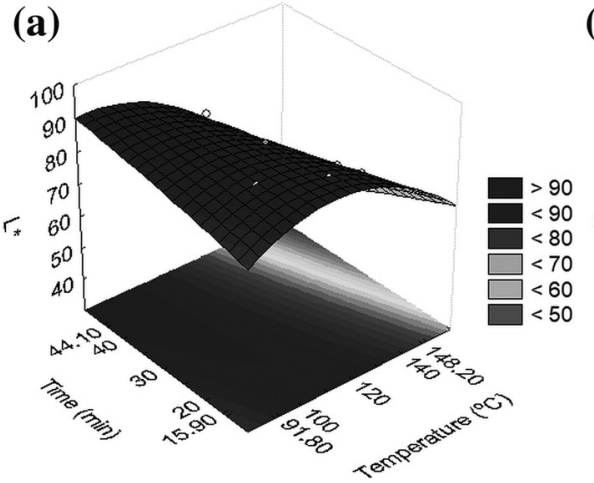

(b)



(c)

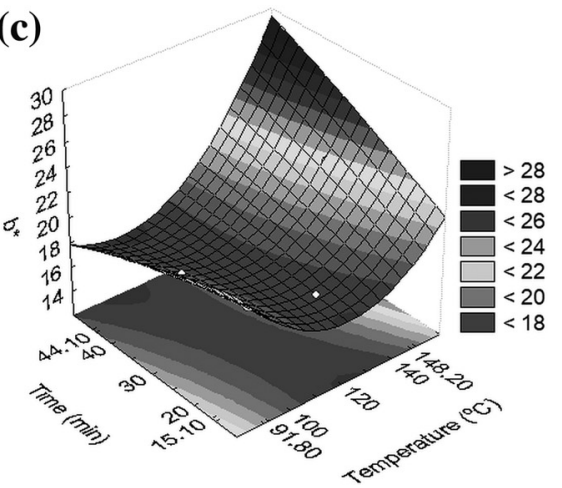

FIGURE 2 Response surface for variables $L *(a), a *(b)$, and $b *(c)$ as a function of temperature and time in the bleached whole soybean flour 

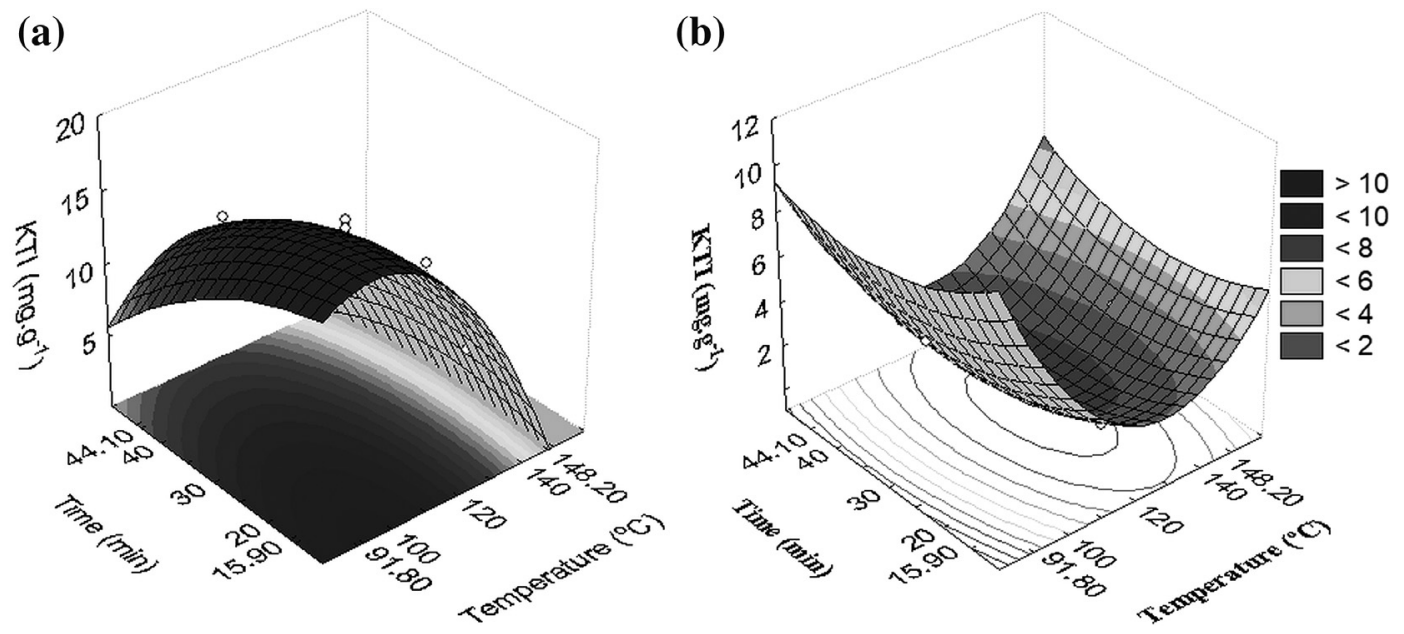

FIGURE 3 Response surface for KTI parameters in whole soybean flour (a) and bleached whole soybean flour (b) as a function of temperature and time

10 and $15 \mathrm{~min}$ thermal treatments at $148.2{ }^{\circ} \mathrm{C}$, the reductions were 66.14 and $75.73 \%$, respectively. Whereas, when applying 20 and 30 min thermal treatment, it allowed 87.14 and $90.58 \%$ maximal reductions, respectively. Therefore, $20-30 \mathrm{~min}$ is a suitable time for trypsin inhibitors inactivation at acceptable levels.

A significant $L^{*}$ color parameter decrease was observed as the time increased, darkening the flour. No significant statistical differences were noted $(p>.05)$ between the 20-30 min time range for chromaticities $a^{*}$ (red tonality) and $b^{*}$ (yellow tonality).

The treatment at $148.2^{\circ} \mathrm{C}$ for 20 and 30 min presented the lowest $K T I$ values, however, at 20 min the $L^{*}$ color value of soybean flour was whiter. Hence, the thermal treatment at $148.2^{\circ} \mathrm{C}$ for $20 \mathrm{~min}$ (whole soybean flour T3) was considered the optimal one for soybean flour production. Proximate composition, PDI, NSI, and fatty acid composition analyses were also performed for this flour.

Lipids, fiber, and ashes contents were similar without any significant difference $(p>.05)$ between in natura grains and whole soybean flour T3, however, a protein content increase occurred (Table 3). This protein value increase could be related to the destruction of protease inhibitors caused by heat. Abdulsalami and Sheriff (2010) reported a substantial increase in crude protein after Bambara groundnut (Voandezeia subterranean) soaking and cooking and attributed this increase to the destruction of anti-nutritional factors resulting in nutrients release.

Zhang, Fan, Li, Zhang, and Gao (2018), observed that the thermal treatment in an oven at 95,110 , and $125^{\circ} \mathrm{C}$ for $30 \mathrm{~min}$ of defatted soybean flour with new intra- and intermolecular bonds (such as hydrogen bonds, hydrophobic interactions, van der Waals forces, and repolymerization of $-\mathrm{SH}$ and $\mathrm{S}-\mathrm{S}$ via interchange reactions) reported that form insoluble aggregates, implying the self-cross-linking or soya bean protein aggregation.

Carbohydrate contents had no statistical difference $(p>.05)$ in the flour in comparison with the grain. However, thermal treatment could cause the caramelization of carbohydrates. According to Martínez, Marín, and Ribotta (2013), caramelization depends on direct degradation of sugars (temperatures $>120^{\circ} \mathrm{C}$ ), since the free amino and carbonyl groups of reducing sugars such as glucose and maltose, are favored by temperature. Agrahar-Murugkar and Jha (2010) also reported this behavior and described that the inhibitors destruction by thermal treatment caused a formation of unnatural amino acids from proteincarbohydrate browning reactions and cross-linked amino acids.

For the grains, it was obtained $5.44 \%$ carbohydrate (Table 3). According to Karr-Lilienthal, Kadzere, Grieshop, and Fahey (2005), the carbohydrate composition varies according to the geographical location (soybean cultivation), harvest conditions, and post-harvest processing.

In natura grains and T3 whole soybean flour could be used as fiber sources. In order to meet the functional food properties and/or \#27 Health Claims requirement (Brasil, 1998), a minimum 11.23 g T3 whole soybean flour intake would be required, since $3 \%$ is the minimum amount as a source of fiber. These values are comparable with those from extruded soy flour, where Dust et al. (2004) observed that the soy flour contained total dietary fiber amounts of $26.6 \%$ for moderate extruded soy flour $\left(100-110^{\circ} \mathrm{C}\right)$ and $24.56 \%$ for extreme extruded soy flour $\left(120-130^{\circ} \mathrm{C}\right)$.

TABLE $2 \mathrm{KTI}$ and color $\left(L^{*}, a^{*}\right.$, and $\left.b^{*}\right)$ values of whole soybean flour at $148.2^{\circ} \mathrm{C}$ and different times

\begin{tabular}{|c|c|c|c|c|c|}
\hline \multirow[b]{2}{*}{ Treatments } & \multirow[b]{2}{*}{ Time (min) } & \multirow[b]{2}{*}{$\mathrm{KTI}(\mathrm{mg} / \mathrm{g})$} & \multicolumn{3}{|l|}{ Color } \\
\hline & & & $\overline{L *}$ & $a^{*}$ & $b^{*}$ \\
\hline $\mathrm{T} 1$ & 10 & $5.61^{a} \pm 0.61$ & $90.83^{a} \pm 0.05$ & $2.36^{c} \pm 0.04$ & $21.42^{b} \pm 0.08$ \\
\hline T3 & 20 & $2.13^{b} \pm 0.69$ & $87.11^{c} \pm 0.36$ & $4.47^{a} \pm 0.12$ & $22.50^{\mathrm{ab}} \pm 0.34$ \\
\hline $\mathrm{T} 4$ & 30 & $1.56^{b} \pm 0.09$ & $79.79^{d} \pm 0.48$ & $4.54^{a} \pm 0.26$ & $22.78^{a} \pm 0.89$ \\
\hline
\end{tabular}

Means ( \pm standard deviations) followed by same letters on the column, represents no significant difference at $5 \%$ level (Tukey test). $L *$ : lightness or brightness, ranging from black (0) to white (100), $a^{*}$ : coordinated chromaticity ranging from green $(-)$ to red $(+)$, and $b^{*}$ : coordinated chromaticity ranging from blue (-) to yellow (+). 
TABLE 3 Composition and fatty acids content (\%) of in natura grains and whole soybean flour (T3)

\begin{tabular}{|ccl|}
\hline Parameters & In natura grains & Whole soybean flour \\
\hline Moisture $^{\mathrm{a}}$ & $8.46^{\mathrm{a}} \pm 0.26$ & $3.83^{\mathrm{b}} \pm 0.07$ \\
\hline Proteins $^{\mathrm{b}}$ & $42.36^{\mathrm{b}} \pm 0.39$ & $46.12^{\mathrm{a}} \pm 0.15$ \\
\hline Lipids $^{\mathrm{b}}$ & $15.50^{\mathrm{a}} \pm 0.67$ & $16.31^{\mathrm{a}} \pm 0.22$ \\
\hline Ash $^{\mathrm{b}}$ & $5.52^{\mathrm{a}} \pm 0.45$ & $5.59^{\mathrm{a}} \pm 0.09$ \\
\hline Carbohydrates $^{\mathrm{b}, \mathrm{c}}$ & $5.44^{\mathrm{a}} \pm 0.74$ & $5.90^{\mathrm{a}} \pm 0.46$ \\
\hline Fiber $^{\mathrm{b}}$ & $22.72^{\mathrm{a}} \pm 0.53$ & $22.25^{\mathrm{a}} \pm 0.67$ \\
\hline PDI & $79.78^{\mathrm{a}} \pm 0.48$ & $16.11^{\mathrm{b}} \pm 0.71$ \\
\hline NSI & $63.58^{\mathrm{a}} \pm 0.52$ & $24.16^{\mathrm{b}} \pm 0.05$ \\
\hline Saturated fatty acids (SFA) & & \\
\hline Palmitic (C16:0) & $13.08^{\mathrm{b}} \pm 0.05$ & $13.30^{\mathrm{a}} \pm 0.08$ \\
\hline Stearic (C18:0) & $3.73^{\mathrm{a}} \pm 0.01$ & $3.71^{\mathrm{b}} \pm 0.01$ \\
\hline Arachidic (C20:0) & $0.36^{\mathrm{b}} \pm 0.01$ & $0.37^{\mathrm{a}} \pm 0.01$ \\
\hline Total & $17.17^{\mathrm{b}} \pm 0.05$ & $17.37^{\mathrm{a}} \pm 0.08$ \\
\hline Monounsaturated fatty acids (MFA) & \\
\hline Oleic (C18:1) & $18.67^{\mathrm{a}} \pm 0.16$ & $18.13^{\mathrm{b}} \pm 0.20$ \\
\hline Polyunsaturated fatty acids (PFA) & \\
\hline Linoleic (C18:2n-6) & $54.81^{\mathrm{a}} \pm 0.13$ & $54.85^{\mathrm{a}} \pm 0.10$ \\
\hline Linolenic (C18:3n-3) & $9.35^{\mathrm{b}} \pm 0.06$ & $9.63^{\mathrm{a}} \pm 0.05$ \\
\hline Total & $64.16^{\mathrm{b}} \pm 0.17$ & $64.49^{\mathrm{a}} \pm 0.15$ \\
\hline Ratio & $3.74^{\mathrm{a}} \pm 0.02$ & $3.71^{\mathrm{b}} \pm 0.01$ \\
\hline UFA/SFA & $5.86^{\mathrm{a}} \pm 0.02$ & $5.69^{\mathrm{b}} \pm 0.02$ \\
\hline n-6/n-3 & & \\
\hline
\end{tabular}

Means ( \pm standard deviations) followed by same letters on the lines, represents no significant difference at $5 \%$ level (Student test).

a Results expressed in integral matter.

${ }^{b}$ Results expressed on dry matter.

${ }^{\text {c }}$ Results calculated by difference [100 - (Moisture + protein + lipids + ash + fiber)], including the fiber fraction.

Due to the thermal treatment applied, it was observed a significant PDI and NSI decrease $(p<.05)$ in the flour in relation to the grain, due to the denaturation. The extent of denaturation depends on processing conditions and temperature. As the thermal treatment was at $148.2{ }^{\circ} \mathrm{C}$ for $20 \mathrm{~min}$, PDI was reduced by approximately $80 \%$ and NSI decreased by $62 \%$. Higher solubility occurred due to low denaturation, despite solubility and denaturation not always correlating with each other. However, denaturation could not be invariably associated with negative aspects. Denaturation is desirable when producing soybean protein for food consumption, mainly as it is associated with antinutritional factors reduction, improving protein digestibility (Gilani, Xiao, \& Cockell, 2012). According to Lusas and Riaz (1995), high PDI soybean flours are more soluble, having highly active enzymes and antinutritional factors, corroborating with the results of the present study, where whole soybean flour with low PDI and KTI was found.

Jideani (2011) cited that soybean flours made from white flakes have about $80 \%$ NSI while those from toasted flakes showed $10-20 \%$ values. Such NSI values were similar to those found in T3 soybean flour from thermal treatment obtained in the present study. Thermal treatments significantly improve water absorption capacity (Moure, Sineiro, Domínguez, \& Parajó, 2006), increasing the dispersibility or wettability of the flour augmenting its use in food formulations. Dispersibility is also quite important, as it improves protein interactions with water.

Fatty acids analysis of in natura grains and T3 whole soybean flour, despite the significant differences, except for the linoleic $(p<.05)$ (Table 3). Thermal treatment increased saturated fatty acids (SFA) and polyunsaturated fatty acids (PFA) contents and decreased monounsaturated fatty acids (MFA) contents. PFA/SFA and $n-6 / n-3$ ratios also decreased. Thus, the reductions were statistically significant, not presenting any change in terms of absolute values, keeping soybeans fatty acid contents within the standards.

About $82 \%$ of in natura soybeans and T3 whole soybean flour total fatty acids were unsaturated. Palmitic acid was predominant among the SFAs, while linoleic acid was most significant for the PFAs, which in conjunction with linolenic acid, represented about $64 \%$ of all fatty acids found in grain and flour.

PFAs are considered essential to the human body and have nutritional advantages as long chain fatty acids (linoleic and linolenic acids) precursors. They are associated with improvements in brain, heart, and immune system performance, as well as having suppressive effects on the onset of cardiovascular, inflammatory, and cancer diseases (Nikolić, Sakač, \& Mastilović, 2011; Simopoulos, 2006, 2008). They also present some disadvantages due to easy oxidation, which may compromise food stability.

Although PFAs are extremely relevant on diets, playing important roles in the body, a balanced $n-6$ and $n-3$ intake is required. High n-6 or $n-3$ precursor concentrations, or a change in their relationship, may induce organic disorders. Excessive n-6 consumption and low n-3 intake lead to cardiovascular and inflammatory diseases, cancer, osteoporosis, and autoimmune diseases, whereas the increase in n-3 consumption and the reduction of $n-6$ intake exert a suppressive effect of these pathologies (Simopoulos, 2006, 2008). The $n-6$ and $n-3$ fatty acids compete with the enzymes involved in desaturation reactions and chain elongation. The $n-6 / n-3$ polyunsaturated fatty acids ratio in this study was 5.86 , above $4-5 \%$ range, which is considered nutritionally adequate (Simopoulos, 2008).

The unsaturated and saturated fatty acids (UFA/SFA) ratio was another indicator used to evaluate the nutritional values of oils and fats, where a higher than 0.45 ratio would be considered ideal for a healthy diet. Reduced values are considered undesirable for diets due to their potential in inducing increased blood cholesterol. Kang, Shin, Park, and Lee (2005) suggested a 1.0-1.5 UFA/SFA minimum ratio to reduce the risks of cardiovascular diseases. In this study, the UFA/SFA ratio values were 3.74 for in natura grains and 3.71 for T3 whole soybean flour, thus, confirming soybean status as healthy food.

\section{4 | CONCLUSIONS}

The experimental design results showed that $148.2^{\circ} \mathrm{C}$ for $30 \mathrm{~min}$ for the whole soybean flour and $120^{\circ} \mathrm{C}$ for $30 \mathrm{~min}$ for the bleached soybean flour had the highest KTI reductions. Both flours at low temperatures and shorter time periods presented light color. As the bleaching process includes an extra step for obtaining soybean flour, the process for whole soybean flour was considered the most appropriate one. When evaluating thermal treatment at $148.2^{\circ} \mathrm{C}$ for different time periods, the lowest KTI values were observed at 20 and $30 \mathrm{~min}$ and white color $L^{*}$ values at $20 \mathrm{~min}$. The soybean flour obtained at $148.2^{\circ} \mathrm{C}$ for 20 min showed good nutritional features (fiber and protein source) with a 3.71 polyunsaturated fatty acids and saturated 
fatty acids ratio, contributing towards improving diets mainly for people in countries with a shortage of such nutrients in their diets.

\section{ACKNOWLEDGMENTS}

The authors would like to thank CNPQ (Universal/CNPq471593/2012-5); EMBRAPA, CAPES, Teacher Training Doctoral Program (PRODOUTORAL), and Rondônia Federal Education Institute (IFRO).

\section{ORCID}

Juliana Steffens (D) https://orcid.org/0000-0001-6607-2283

Clarice Steffens (D) https://orcid.org/0000-0003-4394-125X

\section{REFERENCES}

Abdulsalami, M. S., \& Sheriff, H. B. (2010). Effect of processing on the proximate composition and mineral content of bambara groundnut (Voandezeia subterranean). Journal of Pure \& Applied Science, 3(1), 188-190.

Agrahar-Murugkar, D., \& Jha, K. (2010). Effect of drying on nutritional and functional quality and electrophoretic pattern of soyflour from sprouted soybean (Glycine max). Journal of Food Science and Technology, 47(5), 482-487.

Andrade, J. C., Mandarino, J. M. G., Kurozawa, L. E., \& Ida, E. I. (2016). The effect of thermal treatment of whole soybean flour on the conversion of isoflavones and inactivation of trypsin inhibitors. Food Chemistry, 194, 1095-1101.

AOAC. (2007). Official methods of analysis (18th ed. ed., 2nd revision). Gaithersburg, MD: AOAC International.

AOCS. (1980). Official and tentative methods of the American oil chemists society - Official method Ba 10-65 (3rd ed.). Champaign, IL: AOAC International.

Brasil. (1998). Ministério da Saúde. Agência Nacional de Vigilância Sanitária. ANVISA. Portaria $n^{\circ} .27$, de January 13,1998 . Aprova o regulamento técnico referente à informação nutricional complementar (declarações relacionadas ao conteúdo de nutrientes). Diário Oficial da União; Poder Executivo, de 16 de jan.

Brune, M. F. S. S., Pinto, M. O., Peluzio, M. C. G., Moreira, M. A., \& Barros, E. G. (2010). Biochemical and nutritional evaluation of a soybean line lacking the Kunitz trypsin inhibitor and lectins. Food Science and Technology, 30, 657-663.

Cardoso, L. R., Oliveira, M. G. A., Mendes, F. Q., Pires, C. V., Ribeiro, F. R., Sant'ana, R. C. O., \& Moreira, M. A. (2007). Activity of protease inhibitors in genetically enhanced soy lines. Alimentos e Nutrição, 18, 19-26.

Chen, Y., Xu, Z., Zhang, C., Kong, X., \& Hua, Y. (2014). Heat-induced inactivation mechanisms of Kunitz trypsin inhibitor and Bowman-Birk inhibitor in soymilk processing. Food Chemistry, 154, 108-116.

Christie, W. W. (1989). Gas chromatography and lipids. A practical guide. Ayr, Scotland: The Oil Press.

Ciabotti, S., Barcelos, M. F. P., Pinheiro, A. C. M., Clemente, P. R., \& Lima, M. A. C. (2007). Sensorial and physical characteristics of bleached and lipoxygenase-free soybean milk and curd. Food Science and Technology, 27, 643-648.

Coscueta, E. R., Pintado, M. E., Picó, G. A., Knobel, G., Boschetti, C. E., Malpiedi, L. P., \& Nerli, B. B. (2017). Continuous method to determine the trypsin inhibitor activity in soybean flour. Food Chemistry, 214, 156-161.

Dan, X., \& Ng, T. B. (2016). Two legume defense proteins suppress the mobility of nasopharyngeal carcinoma cells. Journal of Enzyme Inhibition and Medicinal Chemistry, 31, 1-7.

Dust, J. M., Gajda, A. M., Flickinger, E. A., Burkhalter, T. M., Merchen, N. R., \& Fahey, G. C. (2004). Extrusion conditions affect chemical composition and in vitro digestion of select food ingredients. Journal of Agricultural and Food Chemistry, 52, 2989-2996.

Fang, E. F., Leung, H. H., Fang, Y., \& Ng, T. B. (2012). The health benefits of soybeans and Bowman-Birk inhibitor concentrate. Medicinal \& Aromatic Plants, 1, 1-3.
Galão, O. F., Carrão-Panizzi, M. C., Mandarino, J. M. G., Leite, R. S., Claus, T., \& Visentainer, V. J. (2014). Kunitz trypsin inhibitor and phytic acid levels in conventional and genetically modified soybean seeds from Londrina and Ponta Grossa, South Brazil. Acta Scientiarum, Technology, 36, 727-731.

Gemede, H. F., \& Ratta, N. (2014). Antinutritional factors in plant foods: Potential health benefits and adverse effects. International Journal of Nutritrion and Food Science, 3, 284-289.

Gilani, G. S., Xiao, C. W., \& Cockell, K. A. (2012). Impact of antinutritional factors in food proteins on the digestibility of protein and the bioavailability of amino acids and on protein quality. British Journal of Nutrition, 108, S315-S332.

Hamerstrand, G. E. (1981). Trypsin inhibitors in soy products: Modification of the standard analytical procedure. Cereal Chemistry, 51, 42-45.

Jideani, V. A. (2011). Functional properties of soybean food ingredients in food systems. Soybean Tzi-Bun Ng, IntechOpen. DOI: https://doi. org/10.5772/14668. Available from: https://www.intechopen.com/ books/soybean-biochemistry-chemistry

Kang, M. J., Shin, M. S., Park, J. N., \& Lee, S. S. (2005). The effects of polyunsaturated:Saturated fatty acids ratios and peroxidisability index values of dietary fats on serum lipid profiles and hepatic enzyme activities in rats. British Journal of Nutrition, 94, 526-532.

Kaur, S., Sharma, S., Dar, B. N., \& Singh, B. (2012). Optimization of process for reduction of antinutritional factors in edible cereal brans. Food Science and Technology International, 18, 445-454.

Karr-Lilienthal, L. K., Kadzere, C. T., Grieshop, C. M., \& Fahey, G. C. (2005). Chemical and nutritional properties of soybean carbohydrates as related to nonruminants: A review. Livestock Production Science, 97, 1-12.

Lusas, E. W., \& Riaz, M. N. (1995). Soy protein products: Processing and use. Journal of Nutrition, 125, 573S-580S.

Martínez, M. L., Marín, M. A., \& Ribotta, P. D. (2013). Optimization of soybean heat-treating using a fluidized bed dryer. Journal of Food Science and Technology, 50(6), 1144-1150.

Moure, A., Sineiro, J., Domínguez, H., \& Parajó, J. C. (2006). Functionality of oilseed protein products: A review. Food Research International, 39, 945-963.

Nikolić, N., Sakač, M., \& Mastilović, J. (2011). Effect of buckwheat flour addition to wheat flour on acylglycerols and fatty acids composition and rheology properties. LWT - Food Science and Technology International, 44, 650-655.

Shin, D. J., Kim, W., \& Kim, Y. (2013). Physicochemical and sensory properties of soy bread made with germinated, steamed, and roasted soy flour. Food Chemistry, 141, 517-523.

Simopoulos, A. P. (2008). The importance of the Omega-6/Omega-3 fatty acid ratio in cardiovascular disease and other chronic diseases. Experimental Biology and Medicine, 233, 674-688.

Simopoulos, A. P. (2006). Evolutionary aspects of diet, the Omega-6/ Omega-3 ratio and genetic variation: Nutritional implications for chronic diseases. Biomedicine \& Pharmacotherapy, 60, 502-507.

Vagadia, B. H., Vanga, S. K., \& Raghavan, V. (2017). Inactivation methods of soybean trypsin inhibitor - A review. Trends of Food Science and Technology, 64, 115-125.

Vorster, B. J., Schlüter, U., Du Plessis, M., Van Wyk, S., Makgopa, M. E., Ncube, I., ... Foyer, C. H. (2013). The cysteine protease-cysteine protease inhibitor system explored in soybean nodule development. Agronomy, 3(3), 550-570.

Zhang, B.-H., Fan, B., Li, M., Zhang, Y.-H., \& Gao, Z.-H. (2018). Effects of thermal treatment on the properties of defatted soya bean flour and its adhesion to plywood. Royal Society Open Sceince, 5, 1-12.

How to cite this article: Dahmer AM, Rigo AA, Steffens J, Steffens C, Carrão-Panizzi MC. Thermal treatment for soybean flour processing with high-quality color and reduced Kunitz trypsin inhibitor. J Food Process Eng. 2018;41:e12925. https:// doi.org/10.1111/jfpe.12925 